\title{
Positive Analysis on Japanese Individual Investors' Ratio of Risk Asset Holding
}

\author{
Toshihiko TAKEMURA* ${ }^{*}$ Takashi KOZU ${ }^{* *}$, Koichi TAKEDA ${ }^{* * *}$, Toru SUEHIRO
}

Received: March 18, 2018

Revised: May 15, 2018

Accepted: May 20, 2018.

\begin{abstract}
In this article, we investigate the determinants of risk asset holding ratio using micro data collected from a Web-based survey. The findings of the current study indicate that, (1) factors such as subjective excess return, overconfidence and time discount rate make positive effects on the ratio of any risk asset holding (factor such as informal information sources make a negative effect), but the effects of other factors in our model vary with the type of the risk assets. Especially, the information sources used in investments make different effects on each type of the risk assets. (2) Psychological factors such as overconfidence and time discount rate used in behavioral finance increase the ratio of the any risk asset holding.
\end{abstract}

Keywords: Ratio of risk asset holding, individual investors, Web-based survey, Behavioral finance, Japan

JEL Code Classification: G41, D91

UDC: 336.49

DOI: https://doi.org/10.17015/ejbe.2018.021.04

\footnotetext{
*Associate Professor, Faculty of Economics, Saga University, Japan. E-mail: tosihiko@cc.saga-u.ac.jp.

** President, Ricoh Institute of Sustainability and Business, Tokyo, Japan.

E-mail: takashi.kozu@nts.ricoh.co.jp

P*** Professor, Faculty of Economics, Hosei University, Tokyo, Japan. E-mail: ktakeda@hosei.ac.jp

${ }^{* * * *}$ Graduate School of Economics, Hosei University, Tokyo, Japan. E-mail: toru.suehiro@mizuho-sc.com 


\section{Introduction}

Although Japanese institutional investors proactively tend to hold risk assets, the individual investors' risk asset holding seems to be inactive in recent years. According to the Japanese flow of funds accounts (dated June 17, 2016), as of the end of March 2016, the total amount of households' financial assets is around 1,706 trillion $\mathrm{JY}$, and the ratio of deposits and cash in total assets is about $52.4 \%$ (Bank of Japan, 2016). On the other hand, the proportion of risk assets such as bonds, investment trusts and stocks, is only $16 \%$ of households' financial assets. Some articles report that such trend continues since many years (Nakagawa \& Katagiri, 1999; Yonezawa, et al., 1999). Generally, it points out that the stock risk premium observed in the real market is higher than the theoretical value of CCAPM and that we can explain the premium only if it is assumed that the investors are excessively risk-averse. This is called stock risk premium puzzle (Mehra \& Prescott, 1985). For example, such high risk premium deviating from the theoretical value implies the investors' ratio of risk asset holding is lower than the rational level in Japan (Kinari \& Tsutsui, 2009). Investing of individual investors with low proportion of risk asset holding may result in considerable impact on the corporate financing environment. Because it is difficult to use the indirect financing today, some companies need to finance via risk money such as stocks and corporate bonds. By following such money to the companies, many investment opportunities are created. If the financing environment of the companies is changed, the investment behavior of companies would be affected. In this sense, it is important and interested to raise investors' ratio of risk asset holding.

In Japan, the government continues to implement the policy to improve investors' passive attitude toward the risk assets and encourage their investment willingness. Concretely, tax cuts on returns by equity investment are implemented in the period FY 2003-FY 2013. Since the beginning of January 2014, Nippon Individual Savings Account (NISA) has started after the model of ISA (Individual Saving Account) in the United Kingdom. NISA is an incentive system that tax exemption of capital gains and dividend incomes. However, Japanese individual investors would not seem to actively invest in the risk assets even now according to some statistics (Financial Service Agency, Japan, 2014). Here, one question arises. In spite of building such investment incentive, many individual investors invest in the risk-free assets and do not invest in the risk assets. Why aren't they investing in the risk assets by using the incentive system? Behavioral finance gives one suggestion to this question. That is the real investors would affect by psychological factors such as overconfidence and cognitive dissonance.

In this article, we investigate the determinants of the individual investors' risk asset holding ratio in Japan. For the above purpose, we analyse their behaviours using micro data collected from a Web-based survey. Previously, a similar investigation has done by Kinari and Tsutsui (2009) in Japan. They have used a cross-sectional 
dataset collected though a mailing survey. Thus, their results might have changed with the time. In this article, we have certain significance of retesting their results.

This article is organized as follows. First, the literature on investors' investment behavior is reviewed and our behavioral model is shown in Section 2. Section 3 outlines the summary of the Web-based survey and we explain the factors embedded in the model. Section 4 shows the results of the Tobit analysis and provides a discussion on the findings. Finally, Section 5 concludes with limitations and implications of our research.

\section{Related works and our model}

Standard CAPM theory assumes that investors are risk-averse and they invest in both risk-free assets and risk assets, by considering both expected returns of assets and the risk (variance of returns). Under these assumptions, the determinants of investors' risk asset holding are as follows. 1) Their (relative) risk aversion: when investors become more risk-averse, the ratio of risk assets becomes lower. 2) Expected excess returns of risk assets: higher expected excess return increase the ratio of risk asset. 3) Variance: the larger variance results lower ratio of risk asset. Above factors will incorporate in our model to check the validity of the assumptions in CAPM theory.

Here, we mainly introduce the studies with regarding to investing in risk assets in Japan.

The passive attitude of Japanese households investing in risk assets is due to rising the precautionary savings motivation associate with worsened income environment and that high transaction cost disturbs the holding of risk assets (Nakagawa \& Katagiri, 1999; Kinari \& Tsutsui, 2009). These arguments imply that income level and risk asset holding are correlative. Therefore, we assume that Japanese investors with higher income level hold the higher amount of risk assets.

According to some previous researches (Ameriks \& Zeldes, 2004; Iwaisako, 2009; Fujiki, et al., 2012; Yamashita \& Nakamura, 2013), age is one of the influential factors that positively affect the ratio of risk asset holding ${ }^{1}$. For example, investors with long-term investment horizon provide the higher present value of their subsistence level in future. Consequently, they will invest more conservatively (in risk-free assets) for ensuring the subsistence level. Based on that, we assume that the Japanese investors' age has a positive effect on the ratio of risk asset holding.

Further, Kitamura and Uchino (2011), and Yamori (2014), mentioned that investors' resident areas also relate to their ratio of risk asset holding. Because, the investors can decline their transaction costs if they live in urban areas, where many financial institutions locate in. In general, the amount of accessible investment information

\footnotetext{
${ }^{1}$ It is theoretically explained that age has not only positive effect but also negative effect toward the risk assets holding (Fujiki, et al., 2012).
} 
is higher in urban areas. Relatedly, the ratio of risk asset holding tends to be lower for investors in remote areas than urban areas such as Tokyo (Yamori, 2014). Therefore, the possibility of risk asset holding increases among investors in urban areas. Going in line with these points, we assume that the Japanese investors, who live in urban area such as Tokyo, actively hold risk assets.

However, the lack of investment information explained as one reason for not investing in risk assets actively (Kinari \& Tsutsui, 2009; Nogata \& Takemura, 2017; Takemura, et al., 2017). Many investors usually collect evidences to avoid the failure of investment by accessing various information sources such as financial statements or ratings. However, we have found few empirical studies regarding the relationship between information access and investing in the risk assets. But, the effectiveness of accessing these information sources is not very clear. Therefore, the current study investigates the relationship between them.

The most of above studies are done based on disclosed data set such as government statistics. However, recently it is pointed that investing behavior strictly relates with human psychology emerged. For doing this kind of the studies, we need micro data including psychological variables. Unfortunately, in most cases, this data set does not exist. For the purpose of researching it, researchers conduct the survey individually. So, up until a few years ago this kind of studies are slowly accumulated (Takeda, Takemura, \& Kozu, 2013).

The last of this section briefly outlines some of the previous studies in behavioral finance that are relevant to our study, more specifically, on individual investors' investment behavior.

Behavioral finance with a focus on human psychology emerged and came to be widely explored by researchers (Burton \& Shah, 2013; Venezia, 2017). Symbolic of this new movement is started from the "Prospect theory" (Kahneman \& Tversky, $1979 ; 1992)$. The prospect theory explains irrational decisions humans make as a disregarded aspect in the expected-utility theory with reference to their cognitive biases. The prefix behavioral (as in behavioral finance and behavioral economics) is often used in descriptive research, in which actual people's decision-making is explained and predicted, rather than in normative research, which examines rational decision-making processes in psychology. Descriptive research deals with empirical data, which shows humans can make decisions that are far from the norm as suggested in the expected-utility theory.

Previous studies in behavioral finance suggest that various psychological biases influence individual stock investors, the target of our research, driving them to make unpredicted investment decisions. The human propensity for overconfidence is one of the examples of such psychological biases ${ }^{2}$. According to Odean (1998, 1999) and other researchers, overconfident investors tend to trade excessively,

\footnotetext{
${ }^{2}$ For overconfidence, see the survey by Lichtenstein et al., (1982), Harvey (1997), and Skala (2008).
} 
overestimate or underestimate a stock price's serial correlations, and not allocate risk adequately. These behaviors can trigger abnormally high market price volatility. Using classical technical analyses such as momentum strategy (Jegadeesh \& Titman, 1993; 2001) and contrarian strategy (De Bondt \& Thaler, 1985) earn excess returns by exploiting the serial correlation of stock returns, but the problem is that the serial correlation may have emerged as a result of overconfident investors' underand overreaction to new information. In addition, Hong et al. (2005) and Ivkovic and Weisbenner (2007) found that individual stock investors are strongly influenced by word-of-mouth information, or what they hear from people around them, when it comes to making investment decisions.

According to these studies, we assume that the Japanese individual investors with overconfidence (higher level) tend to hold much amount of risk assets. Second, we pick up the time discount rate, which also appears in the traditional Economics. It is known that this factor becomes a trigger of misjudging in various decision-making situations. In general, the time discount rate represents an individual's impatience. In actual financial trading, the irrational behaviors are usually observed (Ikeda \& Tsutsui, 2006; Hiruma \& Ikeda, 2007; Kinari \& Tsutsui, 2009; Kitamura \& Nakashima, 2010). Unfortunately, it is not clear the relation between the time discount rate and holding the risk asset. Therefore, in this article we investigate the relations between them through our analysis.

\section{Web-based survey and dataset}

\subsection{Summary of Web-based survey}

Data collected through a Web-based survey titled "(Japanese) Survey on Individual Investors' Awareness" in February 2015 (hereinafter referred to as the "2015 survey"). Respondents were 1,238 men and women over 20 years of age who were investing in stock or other types of mutual funds (e.g. stock mutual funds, balanced mutual funds) at the time of the survey. The survey contained 50 questions on variety of topics such as how much they were investing, how they funded themselves, how often they traded, and their knowledge on finance. The survey questionnaire is available in the author's website ${ }^{3}$.

Here, we discuss the survey method and our dataset. The survey method that we conducted is a Web-based (Internet) survey. Recently it is extremely difficult to conduct usual social survey such as mailing and it is not expected that the collection rate in the survey is high (all over the world). Consequently, messages and implications of quantitative analysis based on data from the survey become sometimes restrictive ${ }^{4}$. The difficulty of collecting micro data from the survey is barrier against empirical studies. To break this barrier, we employ a Web-based

\footnotetext{
${ }^{3}$ URL<http://ecolab.econ.saga-u.ac.jp/invest/index.html> (in Japanese)

${ }^{4}$ These researches inescapably contain certain weakness of the analytical approach because micro data used in the previous studies are restrictive.
} 
survey. This survey method is well-used in the field of marketing. On the other hand, it is known that this method has the Internet bias. That is, the representativeness of general (intended) population may not be guaranteed because the survey is not necessarily based on a random sampling. This statistical problem has not been solved yet (Couper, 2000; Hoshino, 2009). If subjects are interpreted as individuals who register with a Japanese Internet survey company, we could see no problem and analyse it. It has been suggested that it is not necessarily undesirable to use an Internet survey if the aim of the survey is to offer beneficial information that is useful for individual and organizational decisionmaking (The Japan Institute for Labour Policy and Training, 2005). We presume that the data set is useful for reasonable analysis ${ }^{5}$.

Before the data analysis, we assessed the validity of each questionnaire by examining the time spent to answer the 50 questions. The questionnaires where respondents spent less than half of the average time spent (approximately 8 minutes) were disregarded $(1.7 \%)$ as it seems like they did not put much effort to answer the questionnaires (Kozu, Takemura, \& Takeda, 2012). The quick responses where respondents choose the same number for all questions generate unreliable results at the analysis. Therefore, it requires further examination on how disregarding unreliable data which change the accuracy of the overall analysis. As result of this data screening, the number of respondents decreases up to 1,220. Table 1 summarizes the demographic information of respondents.

Table 1. Demographic characteristics of the respondents

\begin{tabular}{|c|c|c|c|c|c|c|c|}
\hline & & $\#$ & $(\%)$ & & & \# & $(\%)$ \\
\hline \multirow[t]{2}{*}{ Gender } & Male & 907 & 73.3 & \multirow{2}{*}{ Marriage } & Married & 884 & 71,4 \\
\hline & Female & 331 & 26.7 & & Not Married & 354 & 28,6 \\
\hline \multirow[t]{4}{*}{ Age } & 20 's & 58 & 4,7 & \multirow{4}{*}{ Income } & $<1$ million $\mathrm{JY}$ & 204 & 16,5 \\
\hline & 30 's & 256 & 20.7 & & 1-5 million JY & 557 & 45.0 \\
\hline & 40 's & 379 & 30.6 & & 5-10 million JY & 370 & 29,9 \\
\hline & Over 50 years old & 545 & 44.1 & & >10 million JY & 107 & 8,6 \\
\hline \multirow{6}{*}{$\begin{array}{l}\text { Amount of } \\
\text { deposit }\end{array}$} & $<1$ million $\mathrm{JY}$ & 196 & 15.8 & \multirow{6}{*}{$\begin{array}{l}\text { Resident } \\
\text { area }\end{array}$} & Hokkaido/Tohoku & 104 & 8,4 \\
\hline & 1-5 million JY & 462 & 37.3 & & Kanto & 502 & 40,6 \\
\hline & 5-10 million JY & 209 & 16.9 & & Chubu & 234 & 18,9 \\
\hline & >10 million JY & 371 & 30.0 & & Kinki & 233 & 18,8 \\
\hline & & & & & Chugoku/Shikoku & 92 & 7,4 \\
\hline & & & & & Kyushu/Okinawa & 73 & 5,9 \\
\hline
\end{tabular}

\subsection{Definition of variables}

Variables shown in Table 1 such as respondents' (pre-tax) income and age were used directly in our analysis. On the other hand, some other variables were processed as follows.

\footnotetext{
${ }^{5}$ We have no intention of ignoring problem of the Internet bias. Currently, studies on representativeness of data from the Web-based survey are promoted. In the near future, we anticipate development of it and believe to provide a breakthrough of the researches.
} 
Ratio of risk asset holding: We directly asked the ratio of assets such as deposit/foreign currency deposit, domestic/foreign bond, stock investment ${ }^{6}$. Based on the answers to this question, we classified risk assets into three categories as follows.

- $\quad$ risk asset $\mathrm{I}=$ stock investment + domestic bonds + foreign bonds + other types of mutual funds (e.g. stock mutual funds, balanced mutual funds)

- $\quad$ risk asset II = stock investment + domestic bonds + foreign bonds

- $\quad$ risk asset III = stock investment

We calculated the ratio of risk asset holding by dividing these assets by the total assets. Risk asset I was broadly defined and risk asset III was used in a narrow sense.

Figure 1 illustrates the distribution of three categories of ratio of risk asset holding. This result, especially the risk asset III, consistent with the tendency of Japanese risk asset holding as mentioned in Section 1. The broader the definition of risk asset, the more cautious the individual investors tends to be about holding risk assets.

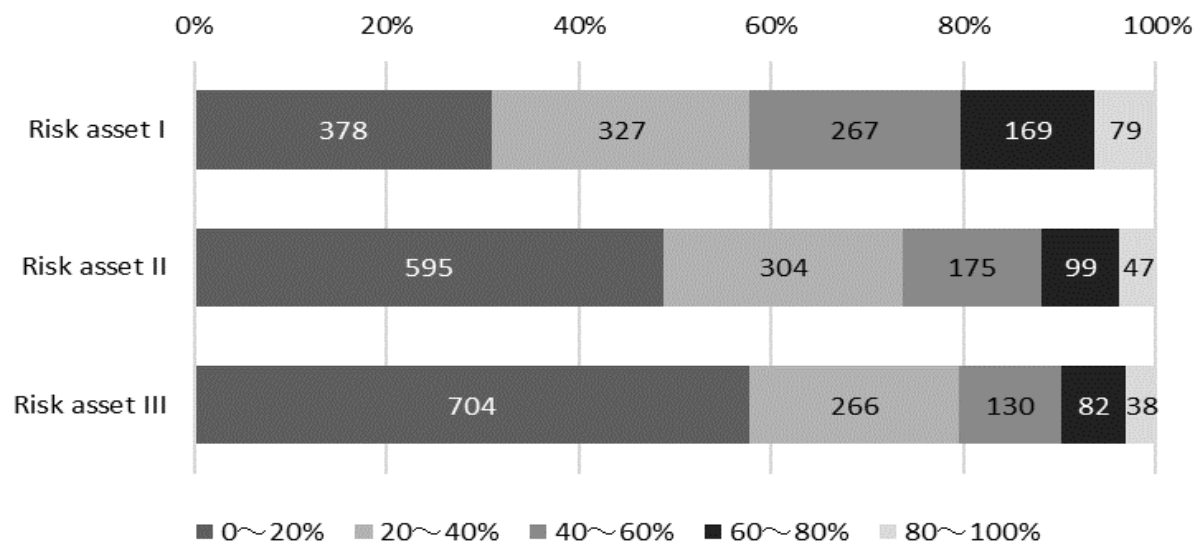

Figure 1. Ratio of risk asset holding

Subjective (expected) excess return: Regarding subjective expected excess return, we used the question: if you are going to invest in assets, what percentage of revenue (per year) you would able to earn with comparing to risk-free asset, such as bank deposit? We asked participants to mention the percentage of the revenue directly.

In this article, we categorized above answers into three based on the percentage of revenue because the respondents' answers were accumulated around particular

\footnotetext{
${ }^{6}$ The average ratio of financial assets is $51.7 \%$ for deposits, $2.7 \%$ for foreign currency deposits, $2.9 \%$ for domestic bonds, $1.5 \%$ for foreign bonds, $2.3 \%$ for bonds with mutual funds type, other mutual funds (stock type, balanced type) $10.4 \%$ for equity investment, $25.4 \%$ for equity investment, $2.0 \%$ for foreign exchange margin transactions and $0.3 \%$ for commodity futures transactions.
} 
values such as $0 \%, 1 \%, 5 \%$ and $10 \%^{7}$. The first category includes the respondents who deem to obtain lower returns than risk-free asset. The second includes the respondents who deem to earn excess returns, but the percentage is less than $5 \%$. The third category includes the respondents who deem to obtain 5\% or more excess returns. Although respondents in the third category tend to feel like bulls, respondents in first category tend to feel like bears.

According to this aggregate result, $5 \%$ of respondents think not to obtain excess returns and $49 \%$ of respondents think to obtain less than $5 \%$ excess returns. In addition, the remaining respondents deem to obtain $5 \%$ or more excess returns.

Risk aversion: Although there are various methods of measuring the degree of risk aversion, we employ a simple method by asking a simple question to mention the chance for rain in case they carry an umbrella when they go out ${ }^{8}$. In this method, it is easy for all respondents to evaluate the risk (expose to the rain) through their day to day experience. For escaping from the rain, they bring an umbrella with them. If they think the probability of raining is low, they would not tend to take an umbrella. Such respondents assessed to be more risk-averse since they take an umbrella even the probability of raining is low. Hence, if we know the chance of rain when they take an umbrella, we would calculate the degree of risk aversion by subtracting their answers from 100 (\%).

Figure 2 shows the distribution of respondents' degree of risk aversion. More than half of the respondents' the degree of risk aversion is high relatively, as they are more risk-averse.

Tokyo dummy: As shown in Table 1, we have the information about respondents' residence area. To test the effect of the residence area, we made a dummy variable, called Tokyo dummy. Here, we assign one if their resident area is Tokyo and when they live in outside Tokyo, the dummy assigns to zero. Tokyo is included in Kanto area, and the number of respondents living in Tokyo is 203 (about 16.4\%).

Information sources used in investment: The 2015 survey asks about the useful information sources when they were investing in stock related assets. Figure 3 illustrates the distributions of the usage in six information sources. While many individual investors use financial statement and stock market as the investment information sources, only a small number of respondents use informal information sources such as hearing from friends.

\footnotetext{
${ }^{7}$ Because the Japanese excess returns at the time was about $5 \%$, we can make a dummy variable based on $5 \%$ of excess returns as a threshold (Suehiro, et al., 2016). However, we judged that it is important to use $0 \%$ of excess return (in ending up breaking even) in addition to $5 \%$ of excess returns.

${ }^{8}$ In behavioral economics, DBM method is often used. For example, by pricing (valuing) of a lottery we can calculate the degree of risk aversion in this method. However, it is sometimes criticized that some individuals may not correctly evaluate the risk of the lottery even if they experience buying the lottery or not (Otake, 2004).
} 
Positive Analysis on Japanese Individual Investors' Ratio of Risk Asset Holding

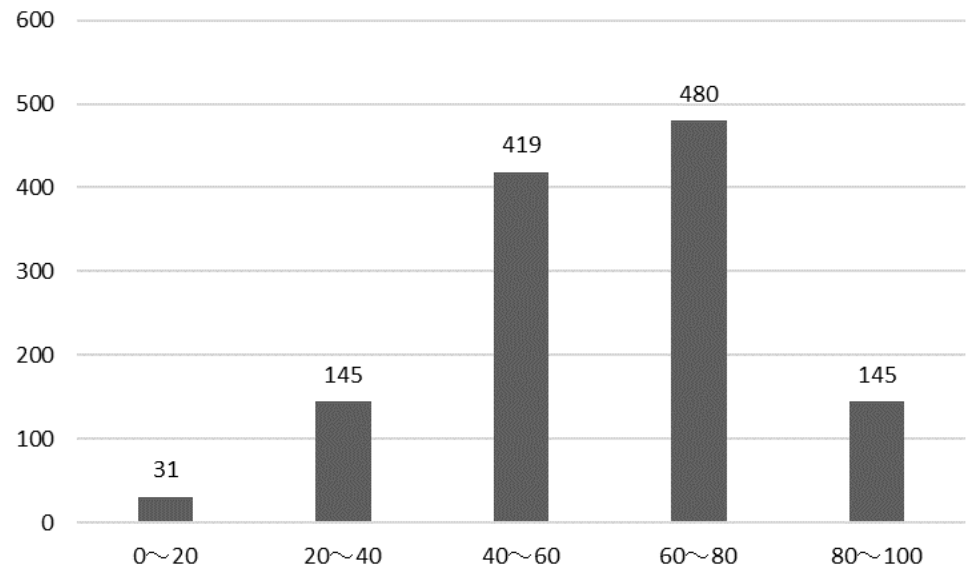

Figure 2. The degree of risk aversion

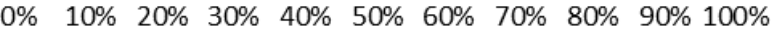

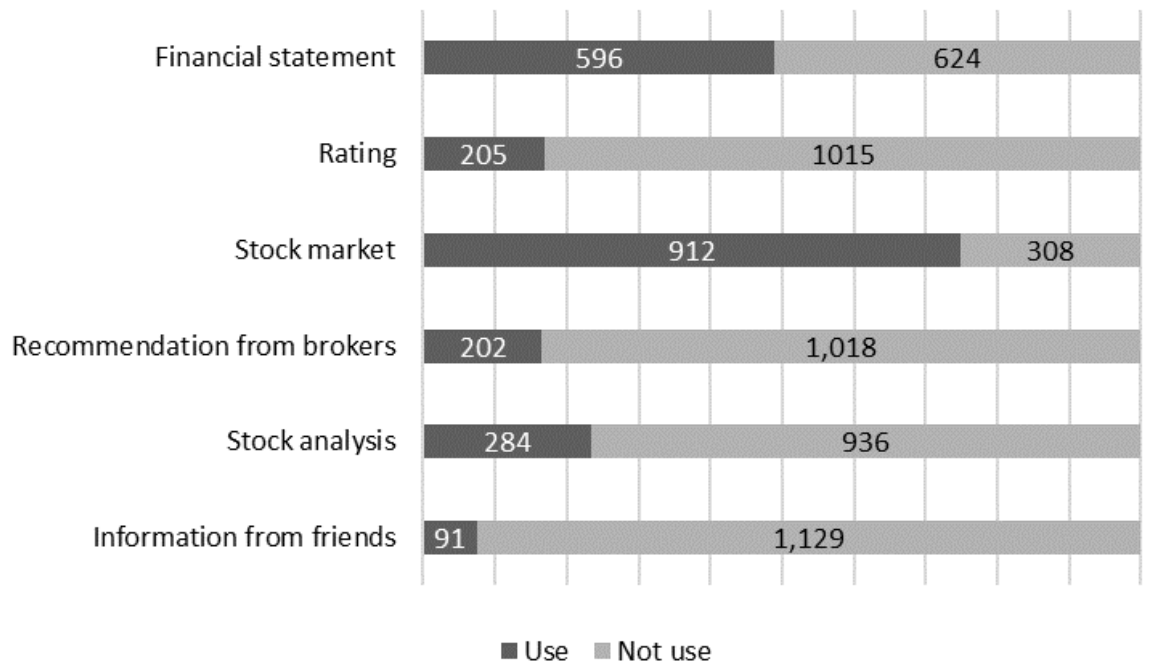

Figure 3. Information sources used in investment

Dummy variables were created for each information source while assigning one for a particular information source used in investment and assigning zero for other sources. Therefore, we have six information source dummies in this study (Nogata \& Takemura, 2017).

Time discount rate: The 2015 survey has some questions based on economic experiment with regarding to time preference conducted in Osaka University (Ikeda \& Tsutsui, 2006). In these questionnaires, the respondents select one of two 
options. one is the amount of money (one million JY) that they receive now, and the other is the amount of money that they receive after one year. The latter is calculated by using interest rate $(0 \%, 0.1 \%, 0.5 \%, 1 \%, 2 \%, 5 \%$, and $10 \%)$. According to that the respondent compares with the amount of them and selects one of them, we would know their switching interest rate. This implies that interest rate which he requires to postpone receiving one million JY after one year.

Figure 4 shows the distribution of the respondents' time discount rate. Many investors (about $23.3 \%$ of the respondents) respond that the time discount rate is $5 \%$. About $82 \%$ of the respondents require $10 \%$ or less time discount rate for postponing receiving one million JY, on the other hand, $9 \%$ of the respondents, who are impatient, cannot postpone receiving one million JY unless the time discount rate is $10 \%$ or more.

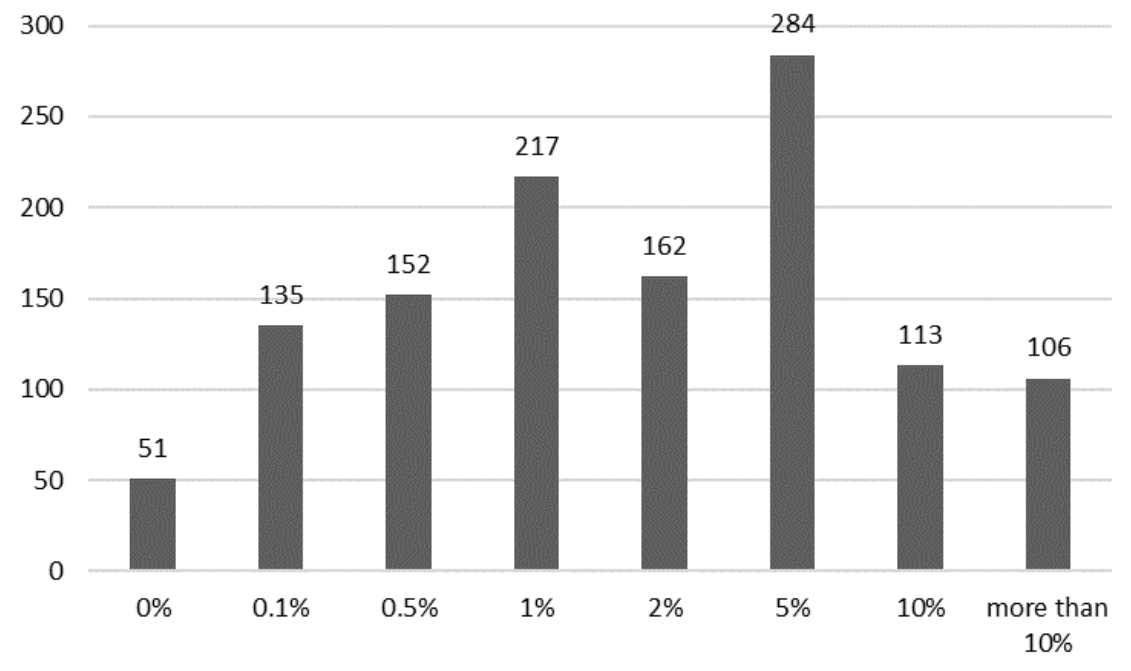

Figure 4. Time discount rate

Overconfidence: As explained by Takeda, et al. (2013), we measure the degree of overconfidence. For the above purpose, we looked at two questions on people's perception of their investment proficiency in the 2015 survey. As the responses given for the first question, we measured subjective financial knowledge (their asset management ability), and we could measure objective financial knowledge by using responses given for the second question, which consist four questionnaire items. The degree of overconfidence is calculated by subtracting respondents' objective financial knowledge from subjective knowledge. If this score has a positive value, we can judge that respondent is an overconfident person. Therefore, higher the score, the respondents tend to be more overconfident.

The distribution of the overconfidence is depicted in Figure 5. It is found that about $45 \%$ of the respondents are overconfident. In addition, $25 \%$ of the respondents are 
confident in asset management and seem to be commensurate with their own financial literacy.

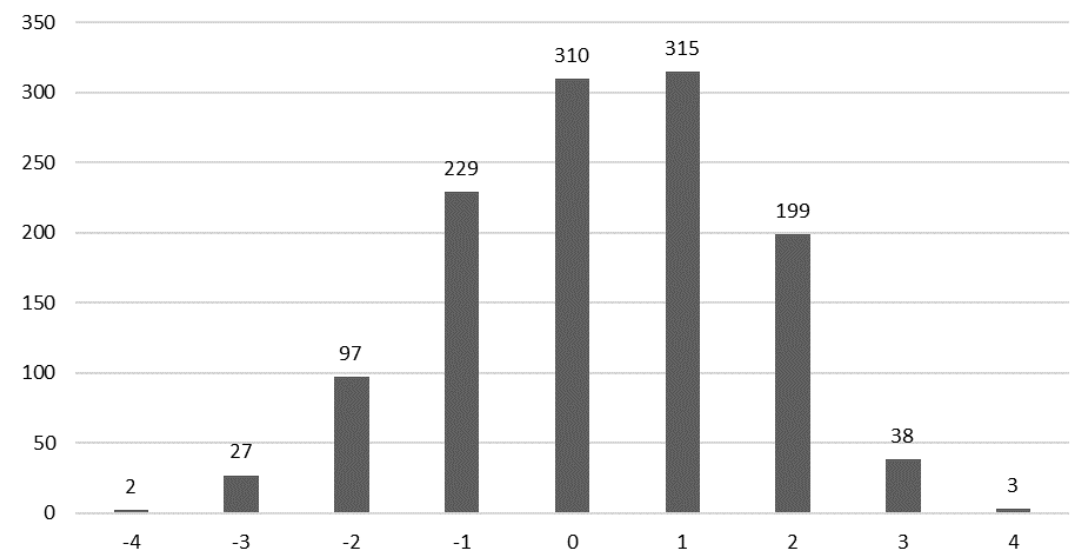

Figure 5. Overconfidence

\section{Analysis}

In this article, three kinds of the ratio of risk asset holding, which is censored data, are explained variables. This is the important feature of the data that complicated the analysis. A linear regression that ignores this feature of the data would be heavily skewed toward underestimating the response of ratio of risk asset holding to the covariates such as income, age, behavioral finance factors. In this case, Tobit analysis is adopted as the standard parametric approach. The Tobit analysis is designed to estimate linear relationships between the explanatory variables and the explained variable censoring from below and above, respectively. Censoring from above takes place when cases with a value at or above some threshold, all take on the value of that threshold, so that the true value might be equal to the threshold, but it might also be higher. In the case of censoring from below, values those that fall at or below some threshold are censored (Green, 2012).

\subsection{Estimation results}

Table 2 shows the estimation results of our Tobit analysis, which explains the variables of ratio of risk asset I holding to ratio of risk asset III holding.

First, in the case of ratio of risk asset I holding, the coefficients of "Age," "Subjective excess return," "Recommendation from brokers" and "Information from friends" are statistically significant at $1 \%$ level. The coefficients of "Time discount rate" and "Stock analysis" are statistically significant at 5\% level and 10\% level, respectively. Only the coefficient of "Information from friends" is negative, while others are positive. 
Table 2. Estimation results

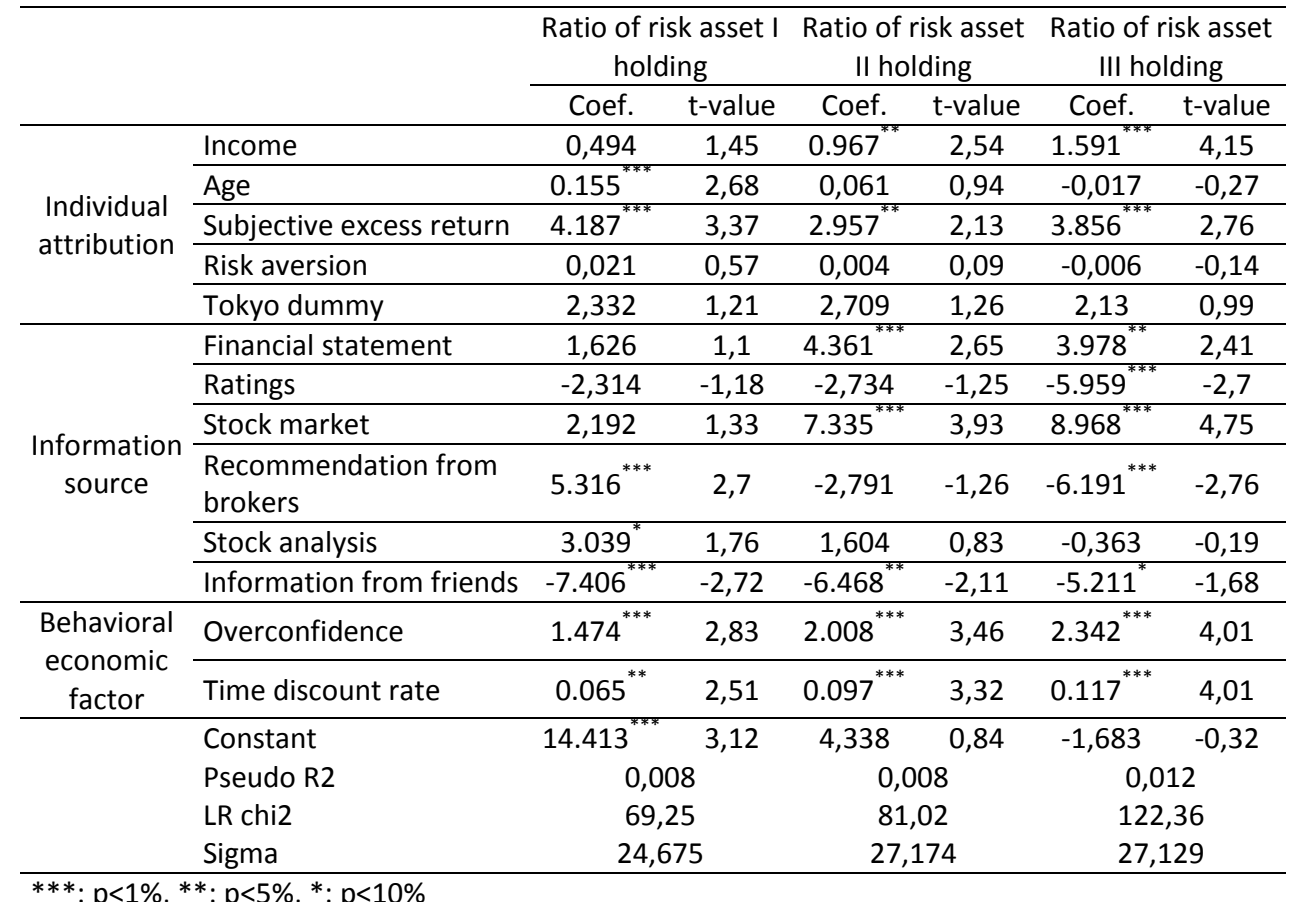

Next, in the case of the ratio of risk asset II holding, "Financial statement," "Stock market," "Overconfidence" and "Time discount rate" are statistically significant at $1 \%$ level. The coefficients of "Income" and "Subjective excess return" are statistically significant at $5 \%$ level. Here also, the coefficient of "Information from friends" is negative, while other statistically significant coefficients are positive. Thirdly, in the ratio of risk asset III holding, the coefficients of "Income," "Subjective excess return," "Ratings," "Stock market," "Recommendation from brokers," "Overconfidence" and "Time discount rate" are statistically significant at $10 \%$ level. The coefficients of "Financial statements" and "Information from friends" are statistically significant at $5 \%$ and $10 \%$ level, respectively. In this case, the coefficients of "Ratings," "Recommendation from brokers" and "Information from friends" are negative and the other coefficients are positive.

As a whole, "Subjective excess return," "Overconfidence" and "Time discount rate" have positive effects on ratio of any risk asset holding, while "Information from friends" has a negative effect. On the other hand, the coefficients of "Risk aversion" and "Tokyo dummy" are not statistically significant in any cases. Further, we found that the other factors are going in line with the definition of risk asset that explained in Section 3.2. In addition, it is interesting to find out the effect of information source, "Recommendation from brokers" is differ at each category of ratio of risk asset holding. 


\subsection{Discussion}

When comparing the ratio of risk asset holding with the ratio of other risk asset holding, the income affects the latter one. Even though we can buy mutual funds even a small amount, the minimum amount of stocks and/or bonds that we tend to buy would be larger. It seems that individuals in elderly age group purchase more amount of stocks and/or bonds while the mutual funds are purchased by wide range of age group. In other words, the young individuals with long investment horizons would prefer to hold risk-free assets rather than purchasing mutual funds. Because they want to ensure their survival in future. With regarding the income, it exhibits a similar trend.

When considering the factors assumed in CAPM theory, the expected exceed return go in line with the assumption of the theory, but the risk aversion is not because the coefficient of the risk aversion is not statistically significant. As found in some previous researches, it is difficult to satisfy the two conditions in CAPM simultaneously. Anyway, the reason for not relating the risk aversion with the ratio of any risk assets could be as follows; the 2015 survey was focused on individual investors who are risk-averse and already holding some risk assets. Furthermore, with the popularization of NISA in Japan, new arrival investors might invest in financial goods with relatively low-price volatility.

The effect on risk asset holding ratio varies with the type of information sources in investment. For example, using informal information sources such as hearing from friends decreases the ratio of any risk asset holding, and using financial statements as the information source, increases the ratio of risk asset I and II holding. In addition, getting recommendation from brokers, increases the ratio of risk asset I but reduces the ratio of risk asset III. Importantly, the effect of information source such as recommendation from brokers is vary with type of risk assets. As an example, when investors use the recommendation of brokers, they tend to purchase more risk assets such as stocks, bonds and mutual funds and they do not try to purchase the less amount of the risk assets as only stocks. When they purchase stocks with high-risk, they comply with the recommendation of brokers. On the other hand, when they purchase mutual funds in addition to stocks and bonds, they think it is not necessary to comply with the recommendations. This could be regarded as that the reliability towards the financial institutions is one of the important factors in ratio of risk asset holding (Kinari \& Tsutsui, 2009). Furthermore, it is very interesting to find out the effect of informal information source such as hearing from friends regrading investments. Using information getting from friends decreases the ratio of any risk assets. This finding reflects the individual investors' desire on more accurate information in investment. Even though, we could able to get information from friends easily regarding investments, the chance to be incorrect information is higher in many cases. 
We can confirm that two factors in behavioral finance, overconfidence and time discount rate increase the ratio of any risk asset holding. The effect of overconfidence is similar with the previous researches (Kinari \& Tsutsui, 2009; Odean, 1998; 1999). On the other hand, the effect of time discount rate is not same as Kinari and Tsutsui (2009) and Kitamura and Nakashima (2010). Accordingly, we conclude that the risk asset holding ratio is affected not only by risk-return relation but also investor's psychological factors up to reasonable level.

\section{Conclusion}

In this article, we investigate the determinants of ratio of risk asset holding by using micro data collected from a Web-based survey. As a result, we can obtain the followings.

First, common factors such as subjective excess return, overconfidence and time discount rate make positive effects on ratio of any risk asset holding (factor such as information from friends makes negative effect), but the effects of other factors in our model vary with the type of the risk assets. Especially, the information sources used in investments, make different effects on each type of the risk assets.

Secondly, we could confirm that psychological factors (overconfidence and time discount rate) use in behavioral finance increase the ratio of the any risk asset holding. This indicates that overconfidence is a factor which deviate the real ratio of risk asset from the optimum ratio presented in the portfolio selection theory. Since, there is a positive relationship between the time discount rate and the ratio of any risk asset holding, the role of time discount rate is not necessary to go in line with Kinari and Tsutsui (2009) and Kitamura and Nakashima (2010). However, the relationship between above variables is not empirically and/or theoretically clear (See Section 2).

Thirdly, compared with the results of Kinari and Tsutsui (2009), it turns out that the behavior pattern of Japanese individual investors has not changed at intertemporal.

Our results have some implication for the government. As mentioned in Section 1, in Japan the individual investors' risk asset holding seems to be inactive. In most cases, for the purpose of increasing the proportion of risk assets, the government often gives the monetary incentive to the individual investors. Of course, such policy is valid, but the effect is few. According to our results, generally considerations of behavioral finance, we may expect that non-monetary incentive is effective to the investors. In addition, it is good that the government prepares the proper information sources for the individual investors' investing in stocks and/or bonds.

Finally, we discuss the limitation of this article and suggestions for the future work. Although our analysis is cross-sectional, we can check the robustness of our analysis by using a new data set collect through the Web-based survey conducted in recent years (because we conduct the survey periodically). We suppose to 
present the results of above mentioned study during the near future. In addition, we should refine some factors used in our model. As an example, it is reasonable to extend the classification of the resident area by examining the scale of the city. According to "Public opinion survey on household financial assets and liabilities" (the Central Council for Financial Services Information) ${ }^{9}$, Yamori (2014), and Takemura, et al. (2017), it is confirmed that there are regional characteristics with regard to various financial behaviors in Japan.

\section{Acknowledgements}

This work was supported by the Japan Society for the Promotion of Science: Grantin-Aid for Scientific Research (C) (17K03827).

\section{References}

Ameriks, J., \& Zeldes, S. (2004). How do household portfolio shares vary with age? Working Paper, Columbia University. $\quad$ Retrieved from https://www0.gsb.columbia.edu/mygsb/faculty/research/pubfiles/16/Ameriks Zeldes age Sept 2004d.pdf

Bank of Japan (2016). Flow of funds: overview of Japan, the United States, and the Euro area (in Japanese). Retrieved from https://www.boj.or.jp/statistics/sj/sjhiq.pdf

Burton, E.T., \& Shah, S.N.(2013). Behavioral finance: Understanding the social, cognitive, and economic debates. New Jersey: Wiley.

Couper, M.P. (2000). Web surveys: a review of issues and approaches. Public Opinion Quarterly, 64, 464-494. https://doi.org/10.1086/318641

De Bondt, W.F.M., \& Thaler, R.H. (1985). Does the stock market overreact? Journal of Finance, 40, 793-808. https://doi.org/10.1111/j.1540-6261.1985.tb05004.x

Financial Service Agency, Japan (2014). About status of using NISA in Japan (in Japanese). Retrieved from: http://www.fsa.go.jp/policy/nisa/20140623-1/01.pdf

Fujiki, H., Hirakata, N., \& Shioji, E. (2012). Aging and household stockholdings: evidence from Japanese household survey data. IMES Discussion Paper Series, 2012-E-17. Retrieved from: https://www.imes.boj.or.jp/research/papers/english/12-E-17.pdf

Green, W.H. (2012). Econometric analysis (seven edition). New Jersey: Prentice Hall.

Harvey, H. (1997). Confidence in judgment. Trends in Cognitive Sciences, 1, 78-82. https://doi.org/10.1016/S1364-6613(97)01014-0

Hiruma, F., \& Ikeda, S. (2007). A study on time discounting based on experiments and an inquiry survey. Review of Monetary and Financial Studies, 25, 14-33 (in Japanese).

Hong, H., Kubik, J.D., \& Stein, J.C. (2005). Thy neighbor's portfolio: word-of-mouth effects in the holdings and trades of money managers. Journal of Finance, 60, 2801-2824. https://doi.org/10.1111/i.1540-6261.2005.00817.x

Hoshino, T. (2009). Statistical science of observed data in the survey: causal inference, selection bias and data fusion, Iwanami Shoten (in Japanese).

\footnotetext{
${ }^{9}$ URL<https://www.shiruporuto.jp/finance/chosa/kyoron_futari/> (in Japanese)
} 
Ikeda, S., \& Tsutsui, Y. (2006). Analysis of risk aversion and time discounting using questionnaire surveys and economic experiments. Securities Analysts Journal, 44(2), 70-81 (in Japanese).

Ivkovic, Z., \& Weisbenner, S. (2007). Information diffusion effects in individual investors common stock purchases: covet thy neighbors' investment choices. Review of Financial Studies, 20, 1327-1357. https://doi.org/10.1093/revfin/hhm009

Iwaisako, T. (2009). Household portfolio in Japan. Japan and the World Economy, 21, 373 238. https://doi.org/10.1016/j.japwor.2009.06.004

Jegadeesh, N., \& Titman, S. (1993). Returns to buying winners and selling losers: implications for stock market efficiency. Journal of Finance, 48, 65-91. https://doi.org/10.2307/2328882

Jegadeesh, N., \& Titman, S. (2001). Profitability of momentum strategies: an evaluation of alternative explanations. Journal of Finance, 56, 699-720. https://doi.org/10.1111/0022$\underline{1082.00342}$

Kahneman, D., \& Tversky, A. (1979). Prospect theory: an analysis of decision under risk. Econometrica, 47, 263-291. https://doi.org/10.2307/1914185

Kahneman, D., \& Tversky, A. (1992). Advances in prospect theory: cumulative representation of uncertainty. Journal of Risk and Uncertainty, 5, 297-323. https://doi.org/10.1007/BF00122574

Kinari, Y., \& Tsutsui, Y. (2009). Determinants of share of risky assets in Japan. Review of Monetary and Financial Studies, 29, 46-65 (in Japanese). Retrieved from: http://www.jsmeweb.org/ja/journal/pdf/vol.29/full paper29jp-kinariandthuthui.pdf

Kitamura, T., \& Nakashima, K. (2010). Household portfolio selection of businessmen aged 30 to 49 years old. Journal of Behavioral Economics and Finance, 3, 50-69 (in Japanese). https://doi.org/10.11167/jbef.3.50

Kitamura, Y., \& Uchino, T. (2011). The effect of academic background on household portfolio selection: evidence from Japanese repeated cross section data. Review of Monetary and Financial Studies, 33, 24-45 (in Japanese). Retrieved from: http://hermes-ir.lib.hitu.ac.jp/rs/bitstream/10086/18657/1/gd10-149.pdf

Kozu, T., Takemura, T., \& Takeda, K. (2012). An attribute analysis of Internet survey on individual investors' stock investment decisions. RISS Discussion Paper Series, 17, 1-16 (in Japanese). Retrieved from http://www.kansaiu.ac.jp/riss/research/publications/public files/riss dp/RISS DP No17.pdf

Lichtenstein, S., Fischhoff, B., \& Phillips, L.D. (1982). Calibration of probabilities: the state of the art to 1980 in D. Kahneman, P. Slovic and A. Tversky Judgement under uncertainty, Cambridge University Press, 306-334.

Mehra, R., \& Prescott, E. (1985). The equity premium: a puzzle. Journal of Monetary Economics, 15, 145-161. https://doi.org/10.1016/0304-3932(85)90061-3

Nakagawa, S., Katagiri, T. (1999). Portfolio selection of financial assets by Japan's households: Why are Japan's households reluctant to invest in risky assets? Retrieved from https://www.boj.or.jp/en/research/brp/ron 2000/data/ron0009a.pdf

Nogata, D., \& Takemura, T. (2017). Analysis on Japanese individual investors' ratio of risk asset holding: the role of information source. Individual Financing, Summer 2017, 17-24 (in Japanese). $\quad$ Retrieved from https://www.yu-chof.jp/publication/personalfinance/report/2017summer/feature articles03.pdf 
Odean, T. (1999). Do investors trade too much? American Economic Review, 89, 1279-1298. https://doi.org/10.1257/aer.89.5.1279

Odean. T. (1998). Volume, volatility, price, and profit when all traders are above average. Journal of Finance, 53, 1887-1934. https://doi.org/10.1111/0022-1082.00078

Otake, F. (2004). Unemployment and happiness. The Japanese Journal of Labour Studies, 528, 59-68 (in Japanese). Retrieved from http://eforum.jil.go.jp/institute/zassi/backnumber/2004/07/pdf/059-068.pdf

Skala, D. (2008). Overconfidence in psychology and finance: an interdisciplinary literature review. Bank i Kredyt, April, 4, 33-50. Retrieved from https://mpra.ub.unimuenchen.de/26386/1/MPRA paper 26386.pdf

Suehiro, T., Takeda, K., Kozu, T., \& Takemura, T. (2016). Effect of inflation expectations on the equity investment ratio of individual equity investors captured through internet-based surveys. Securities Analysts Journal, 54(10), 78-87 (in Japanese).

Takeda, K., Takemura, T., \& Kozu, T. (2013). Investment literacy and individual investor biases: survey evidence in the Japanese stock market. The Review of Socionetwork Strategies, 7(1), 31-42. https://doi.org/10.1007/s12626-012-0031-z

Takemura, T., Suehiro, T., Kozu, T., \& Takeda, K. (2017). Attribution analysis on the individual investors' ratio of risk assets holding in Japan. CRES Working Paper Series, FY2017-01 (in Japanese). Retrieved from http://cres.eco.saga-u.ac.jp/wps/CRES-WP FY201701Abstract.pdf

The Japan Institute for Labour Policy and Training (2005). Can the Internet survey be used for the social survey?: A result by experiment. Reports on Labour Policy, 17 (in Japanese). Retrieved from http://www.jil.go.jp/institute/reports/2005/documents/017.pdf

Venezia, I. (2017). Behavioral finance: where do investors' biases come from? London: World Scientific.

Yamashita, T., \& Nakamura, T. (2013). The current trend in portfolio selection of financial assets by Japanese households. Journal of the University of Marketing and Distribution Sciences, 25(2), 49-61, (in Japanese). Retrieved from https://ryuka.repo.nii.ac.jp/?action=repository uri\&item id=91\&file id=22\&file no=1

Yamori, N. (2014). Financial behaviors and financial literacy from the viewpoints of region (1): preliminary consideration based on the opinion survey on the financial behaviors in household by The Central Council for Financial Services Information. RIEB Discussion Paper Series, DP2014-J10 (in Japanese). Retrieved from http://www.rieb.kobeu.ac.jp/academic/ra/dp/Japanese/dp2014-J10.pdf

Yonezawa, Y., Matsuura, K., \& Takezawa, Y. (1999). Seniority-based wage system and demands for stocks: why the demand for stocks is small in Japan? Gendai Finance, 6, 3-18 (in Japanese). 